\title{
Cultural and Language Effects of Migration: The Case of Migrants and Chuvash People in the Republic of Bashkortostan (Russia)
}

\author{
Olga Kobzeva ${ }^{1}$ \\ National University of Uzbekistan named after Mirzo Ulugbek, Tashkent, Uzbekistan \\ Elena Kolomoets \\ Moscow Aviation Institute (National Research University), Moscow, Russia
}

Artem Lukyanets

Moscow State Institute of International Relations (MGIMO) Institute of Socio-Political Research FCTAS RAS, Moscow, Russia

Larisa Korotaeva

Sterlitamak Branch of the Federal State Budgetary Educational Establishment of the Higher Education "Bashkir State University”, Sterlitamak, Republic of Bashkortostan, Russia

\begin{abstract}
According to the World Migration Report there are 11.6 million migrants in Russian Federation, the majority of which (43\%) have come from countries of Central Asia: Kazakhstan, Kyrgyzstan, Tajikistan, Turkmenistan, and Uzbekistan. The study aims to evaluate the impact of migration on both migrant and host cultures to establish the changes in native languages and cultures of migrant ethnic groups in the Russian Federation under the influence of a single state language. For the study, the authors used statistical data of the Russian Federal State Statistics Service, findings of the 19202010 censuses, and mathematical modeling of cultural changes based on differential equation. The case of Chuvash people living in the Republic of Bashkortostan was explored by the mathematical modeling method to identify the alien cultural influence on the recipient country, with a particular emphasis on changes in the local language. The direct correlation has been found between the extent to which the migrant community preserve their homeland traditions at a new place and the probability of shifts in the host country's culture. The preservation of migrants' native language in everyday living demonstrates a high probability of replacing the host language by the migrant one in their environment (the probability is $5-10 \%$ higher than the expected level for 7 districts and 11 to $50 \%$ in 8 districts out of 26 studied). The results may have practical use in evaluating the probability of major cultural shifts across the world as the international mass migration increases in volume and scope. Keywords: acculturation, cultural fusion, mathematical model, Russian Germans, transregional migration.
\end{abstract}

\footnotetext{
${ }^{1}$ Correspondent Author E-Mail: kobzevaolg35@ rambler.ru
} 
Migration exists as long as human beings do (Bhugra et al., 2020). Today, there are approximately 272 million international migrants worldwide (United Nations Department of Economic and Social Affairs, 2020). All migrants bear the culture of the nations they belong to by effect of being born and raised in that environment, where they have lived and inherited a set of values, particular lifestyle, and behavioral models (Bhugra et al., 2020). It is not clear what happens with all that background once the bearer moves to a country with a different culture. Furthermore, while examining the impact of migration on cultural setting, the cultural impact of internal replacement within the national boundaries should be given proper consideration too. This is especially true for large states with many regional and ethnic differences, for example, the USA, the Russian Federation, and others.

The paper offers insights into the shifts in migrants' culture as their settlement area changes on the example of ethnic Germans and Greeks in Russia. Moreover, the impact of an alien culture on the host one has been investigated on the example of autochthons of Chuvash Republic that have migrated to Bashkortostan within the Russian Federation. For the first time, the mathematical model was applied to explore the impact of the Chuvash culture on the population of Bashkortostan to evaluate the likelihood of migrant-driven changes in the cultural traits of innate residents. The model, as mentioned above, can be applied to the evaluation of probable cultural shifts in any world nation exposed to migration. Similar studies can be conducted to estimate the world's cultural transformations due to globalization and figure out whether each nation will be able to keep its cultural identity afloat or one global culture will prevail.

\section{Literature Review}

The migrated newcomers bring their cultural assets to another country (Bhugra et al., 2020). Thus, after a migrant is in a new place, his/her cultural scenario may follow either of two possible ways: preserving the traditional cultural background despite the stress or engaging in prolific interactions with the new cultural environment (Nayar \& Wright St.Clair, 2020; Zhanbossinova et al., 2019). Under the latter scenario, the migrant can choose to entirely merge $\mathrm{him} /$ herself into a new cultural setting, leaving behind his/her native culture (get assimilated), or attempt matching both cultural backgrounds (Urzúa et al., 2017). In any case, newcomers are not only dependent upon predominant culture, but they are also bound to communicate with the alien culture bearers (Croucher \& Kramer, 2017). At the same time, the foreign language, unfamiliar social customs, and unusual lifestyle may cause a sense of alarm, loneliness and deprive the peace of mind (Syzdykova et al., 2020). Thus, children with migrant backgrounds do not easily adapt to schooling, which in turn results in lower self-esteem and standing (Haenni Hoti et al., 2019; Rasool \& Zhang, 2020; Schachner et al., 2017). Besides, even migrants of the next generation can feel the trace of migration when adapting to school (Melkonian et al., 2019). The process of acculturation impacts migrants' health as well (Fox et al., 2017). In all cases, migrants seek support from their families, their culture and this is a reason why one tends to preserve one's native culture (Urzúa et al., 2017).

The very task of adapting to a new culture is complex, presuming several stages such as enculturation, deculturation, and acculturation. The entire process often culminates in assimilation (Croucher \& Kramer, 2017). In the first stage of assimilation, a newcomer's culture by merging with the dominant culture becomes a hybrid form where the dominant culture has a significant share, with the newcomer's culture being left unnoticed (Croucher \& Kramer, 2017). Just to assume that bearers of such hybrid cultures, which are formed on an ongoing basis worldwide, interact in some way, a kind of the shared culture might be expected as a result - a multiculture comprising specific traits of national cultures in their diversity (Croucher \& Kramer, 2017). The problem of acculturation is relevant not only for migrants but also for 
indigenous population of a country since not only culture but also economic and political wellbeing of a country depend on migrants (Jamal et al., 2019).

That is why today various countries consider closely the migrants' acculturation theme. In particular, this concerns the Turks in the Netherlands (Jamal et al., 2019), migrants in Portugal (Melkonian et al., 2019; Schachner et al., 2017), in Chile (Urzúa et al., 2017), Belgium, Finland, Italy, Denmark and Slovenia (Schachner et al., 2017). A vast number of recent studies also focus on migration to Russia (Ryabichenko \& Lebedeva, 2016; Sardadvar \& Vakulenko, 2020), including from countries of Central Asia: Kazakhstan, Kyrgyzstan, Tajikistan, Turkmenistan, and Uzbekistan (Gurieva et al., 2020; Nasritdinov, 2016; Nikiforova \& Brednikova, 2018; Ryazantsev et al., 2017). Studies explore the reasons for migration (Sardadvar \& Vakulenko, 2017) and its impact on different spheres, including social and economic development of countries (Ruchkin et al., 2019), in particular in the Republic of Bashkortostan (Khilazheva, 2019; Safiullin et al., 2017).

Despite numerous studies dedicated to migration and its varied influence on the receiving country, there is little research on Chuvash migrants' acculturation in the Republic of Bashkortostan, with no data available on the impact of the Chuvash background on the culture of the Republic. Studies of the historically long fate of migrants in the United States and Canada demonstrate trends in the preservation of national culture and language in Chinese and other ethnic communities in accordance with the same principles that were observed among the Chuvashes and other peoples in Russia (Paquet \& Xhardez, 2020; Paulsen, 2020). The most recent studies in the field of cultural integration of migrants indicate that the society of the host country has focused primarily on economic integration (Gurer, 2020; Paquet \& Xhardez, 2020). General trends both in migration policy and in the behavior of national groups of migrants in different societies (the United States, Canada, and the Russian Federation) are especially noticeable in the old migrant families of Greeks (Dounia, 2020). They strictly preserve their cultural identity and language as a tool for implementing many significant social functions.

Many studies are focused on international migration and its impact on cultural and other spheres of life of a host country, while the novelty of the present study lies in regional context of migration. This study seeks to analyze the cultural influence of internal interregional migration within one country, considering the Russian language as a single state language, which should be known by representatives of all nationalities of the Russian Federation.

\section{Problem Statement}

The cultural fusion relies on both changes in person exposed to a new cultural setting and the culture itself. The paper focuses on ethnic Germans and Greeks in Russia to study shifts in migrants' culture. The study also analyzes migrant culture's impact on native residents on the example of Chuvash people, which have moved to Bashkortostan many centuries ago. The mathematical model underlying the research allows evaluating the shifts in migrants' and autochthones' cultural traits under cultural fusion.

The research question is how the use of the native ethnic language changes among migrants in certain regions under the influence of a single state language, which is mandatory for every member of society. The study aims to establish the change in the ethnic language use on the example of Chuvash people in one of the regions of the Russian Federation. The goal is achievable through several specific objectives, including:

- a search of historical data on the focal issue, especially regarding the cultural shifts among ethnic Germans migrated to Russia;

- the evaluation of new features in Russian culture induced by ethnic Germans and Greeks; 
- the analysis of census findings to find out the proportion of ethnic Chuvashes in the population of the Republic and those of them speaking the Chuvash language;

- application of the mathematical modeling method to assess probability of the indigenous language replacement under the influence of Chuvash language;

- defining the dependence between the probable shifts in the residents' language and the share of migrants preserving their native language in case of Chuvash minority in the Republic of Bashkortostan.

\section{Methods}

The study used the secondary data provided by Russian Federal State Statistics Service and findings of the 1920-2010 censuses to define the changes in the proportion of ethnic German and Greek population in Russia and, respectively, the Chuvash community in Bashkortostan. The method of statistical analysis was applied to look into dynamics of migration flows in 2011-2018 and to see the current trends and migrant-induced implications in local cultural context (Khilazheva, 2019). The same sources were used to find out the areas where migrant communities of Germans, Greeks, and Chuvashes are settled most densely. Census data helped the authors to define the size of German, Greek, and Chuvash population in these areas. Data on changes in the culture of German, Greek, and Chuvash migrants living in Russia over time were sourced in the earlier research focused on these issues.

Beyond that, the applied mathematical model (Erten et al., 2018) allowed measuring the probability of changes in cultural traits of the specific culture bearers as a result of interaction with other culture bearers.

Cultural changes are described using the differential equation:

$$
\frac{d p_{i}}{d t}=\frac{1}{N} \cdot\left[m \cdot\left(1-p_{i}\right)+(1-m) \cdot\left[\left(1-p_{i}\right) \cdot p_{i} \cdot X_{i r} \cdot(\Delta S)\right]\right]
$$

where $N$ is the population size of a country, $m$ is a migration factor (probability of migration at each time interval with the additional probability of its occurrence $(1-m)), p_{i}$ is a relative frequency of the $i$ type, $X_{i r}$ is a probability of interaction between two members of a different culture, $\Delta S$ is a difference in probability of cultural shifts in a resident's and a migrant's culture.

Therefore, the probability of changes in the cultural pattern of an individual exposed to the foreign culture was measured using the above equation. The following formula has been used to define the relative frequency of changes in the migrant culture:

$$
p_{i}^{*}=\frac{m}{1-m} \cdot \frac{1}{\Delta c} \cdot \frac{1}{X_{i r}}
$$

where $\Delta c$ is a difference between a migrant's and a resident's rates of cultural conservatism.

Certain simplification and substitutions have been done in the equation, in particular, assuming that the relative frequency of a migrant's culture type $p_{i}^{*}=1$, whereas $X_{i r}=1$ stands for the probability of interaction between two individuals with different cultural background. The difference between probabilities of shifts in a resident's and a migrant's culture was defined as a difference between a migrant's and a resident's rates of cultural conservatism, $\Delta S=\Delta c$.

Ultimately, the following formula determines the likelihood that a resident's cultural type will change: $\Delta S=\frac{m}{1-m}$. 
The study has also used population statistics of the Republic of Bashkortostan, its national diversity by district (Russian Federal State Statistics Service, 2020), and information from reference sources about languages that are mostly used by the population of Bashkortostan. Usage of the Chuvash language by the population of the Republic and presence of a peculiar dialect were assumed to prove the fact that the native culture of Chuvash people (who formerly migrated to this area) was preserved in the new areas of settlement.

\section{Results}

The Russian Federation is notable for its multinational diversity. It is a home for over 160 ethnic cultures belonging to either migrants or descendants of those who once migrated to Russia for some reason. According to the World Migration Report (International Organization for Migration, 2020), 1,1640,559 immigrants came to the country from 148 countries during 1990-2019. Top 20 countries of immigrants' origin in Russian Federation are shown in Figure 1.

\section{Figure 1}

Top 20 Countries of Immigrants' Origin in the Russian Federation

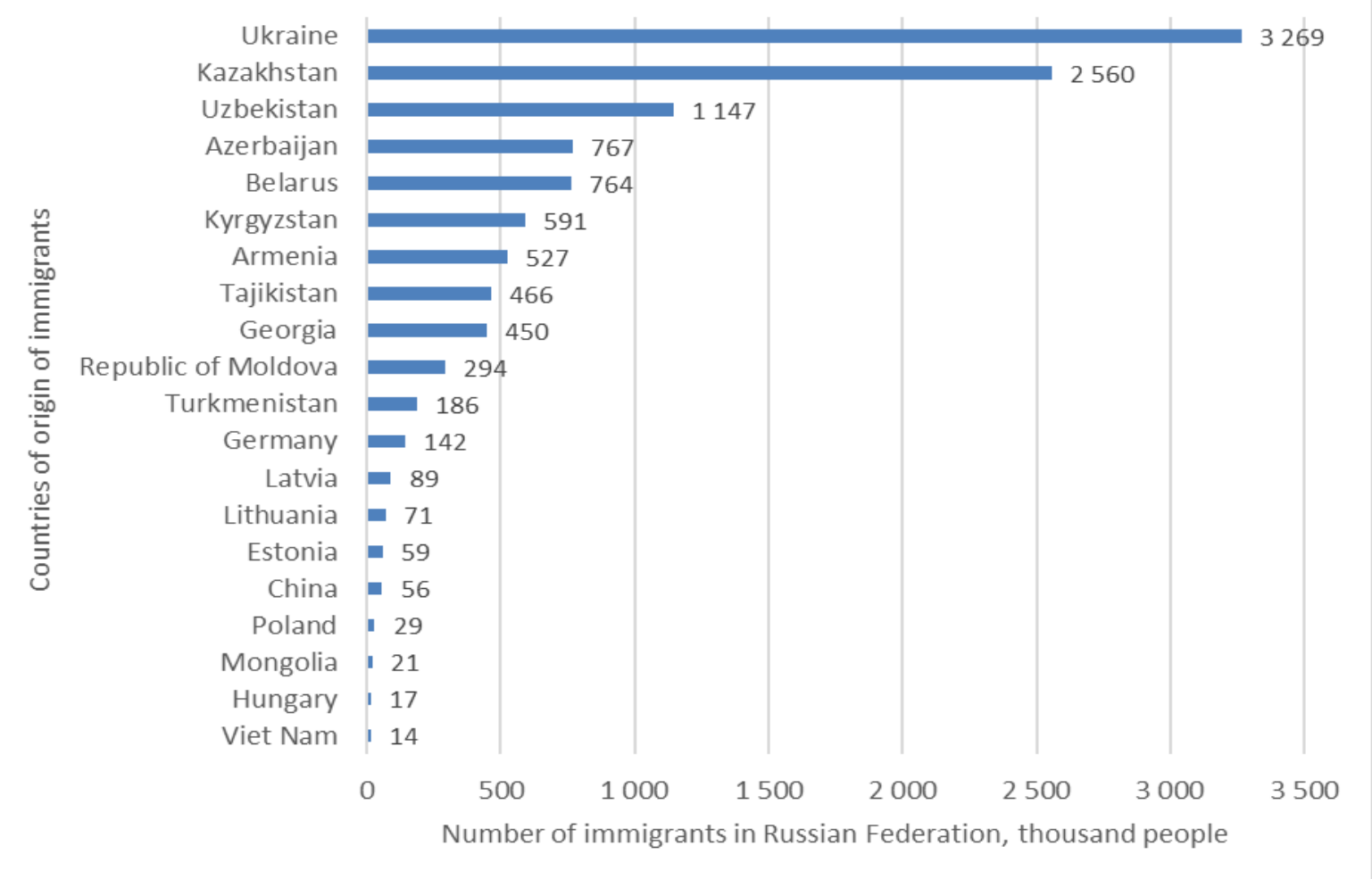

Source: developed by the authors based on World Migration Report (International Organization for Migration, 2020)

95\% of immigrants originate from 12 countries; there are five Central Asian countries (43\% in total): Kazakhstan (22\%), Uzbekistan (10\%), Kyrgyzstan (5\%), Tajikistan (4\%), Turkmenistan (2\%); 28\% of immigrants came from Ukraine (Figure 2). 


\section{Figure 2}

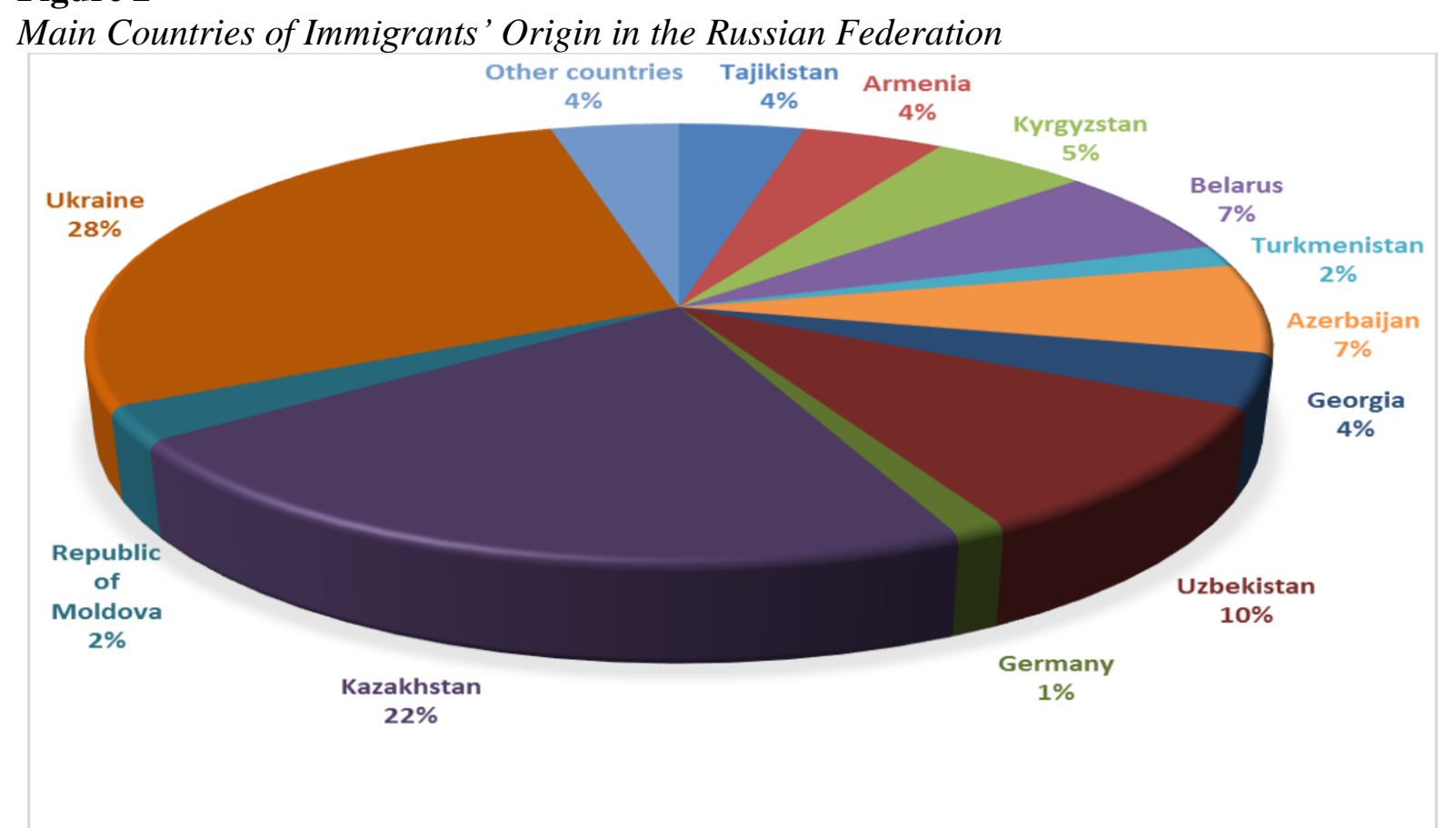

Source: developed by the authors based on World Migration Report (International Organization for Migration, 2020)

The ways for the migrants' descendants to preserve the culture of their homeland on Russia's grounds and the impact of such culture on locals have been explored on the example of ethnic Germans and Greeks, which account for $0.28 \%$ and $0.06 \%$, respectively, in the total population of the country.

References about the above ethnic groups in Russia are given in Table 1, along with the areas most densely inhabited by these communities.

Germans come together in various organizations to preserve the traditions, language, and culture of their homeland. The analysis has shown that, to date, Russian Germans hardly speak their mother tongue at home, German is taught as a foreign language since the second year at school. A similar trend in preserving the native culture is observed in the case with the Hellenic community, which has formed in Russia many centuries ago.

The native culture is argued to be exposed not only to global migration flows but the intrastate population transfer too. Thus, the study of transregional migration impacts of Chuvash community on the Republic of Bashkortostan was held with a peculiar focus on the language aspect. The proportion of Chuvash people in the total population of the Bashkortostan Republic tended to range between $2.5-3.5 \%$ over the last 100 years.

Table 2 sets the findings of the statistical analysis and mathematical modeling of changes, which may occur in the language of natives under the Chuvash people's influence. The Chuvash population in Bashkortostan over the last decades has neither increased through natural population growth (the birth rate has dropped) nor through migration. The current cultural proportions may not change if the trend persists in the nearest future. 


\section{Table 1}

Number of Ethnic Germans and Greeks and Their Public Organizations in Russia

\begin{tabular}{|c|c|c|c|c|c|c|}
\hline Migrants & $\begin{array}{l}\text { Share in } \\
\text { total } \\
\text { populatio } \\
\text { n, \% }\end{array}$ & $\begin{array}{c}\text { Area of } \\
\text { settleme } \\
\text { nt }\end{array}$ & $\begin{array}{c}\text { Share in } \\
\text { the total } \\
\text { number } \\
\text { of } \\
\text { migrants } \\
, \%\end{array}$ & $\begin{array}{c}\text { Share in } \\
\text { the local } \\
\text { populatio } \\
\text { n, \% }\end{array}$ & $\begin{array}{l}\text { Native } \\
\text { langua } \\
\text { ge } \\
\text { usage }\end{array}$ & $\begin{array}{l}\text { Autonomies and } \\
\text { institutions } \\
\text { supporting the } \\
\text { native culture } \\
\text { conservation }\end{array}$ \\
\hline \multirow[t]{2}{*}{ Germans } & 0.28 & $\begin{array}{l}\text { Altai } \\
\text { Territory }\end{array}$ & 2.1 & 2.2 & \multirow{2}{*}{$\begin{array}{l}\text { Study } \\
\text { German } \\
\text { as a } \\
\text { foreign } \\
\text { languag } \\
\text { e at } \\
\text { school }\end{array}$} & $\begin{array}{l}\text { Nemetsky (German) } \\
\text { National District }\end{array}$ \\
\hline & & $\begin{array}{l}\text { Omsk } \\
\text { Region }\end{array}$ & 2.6 & 2.6 & & $\begin{array}{lr}\text { Azovsky } & \text { Nemetsky } \\
\text { (German) } & \text { National } \\
\text { District } & \end{array}$ \\
\hline \multirow[t]{2}{*}{ Greeks } & 0.06 & $\begin{array}{l}\text { Stavropol } \\
\text { Territory }\end{array}$ & 39.2 & 1.2 & \multirow[t]{2}{*}{$\begin{array}{l}\text { Greek } \\
\text { lessons } \\
\text { at } \\
\text { festivals } \\
\text { Study } \\
\text { Greek } \\
\text { at the } \\
\text { Greek } \\
\text { School, } \\
\text { at the } \\
\text { Center } \\
\text { of } \\
\text { Nationa } \\
1 \\
\text { Culture } \\
\text { s }\end{array}$} & $\begin{array}{l}\text { Federal national and } \\
\text { cultural autonomy } \\
\text { (FNCA) of Greeks } \\
\text { of Russia, Stavropol } \\
\text { Municipal Greek } \\
\text { Supplementary } \\
\text { School, Stavropol } \\
\text { Municipal National } \\
\text { and Cultural } \\
\text { Autonomy of } \\
\text { Greeks. } \\
\text { Museum of History, } \\
\text { Culture and } \\
\text { Ethnography of the } \\
\text { Stavropol Greeks, } \\
\text { Folk Dance Group } \\
\text { "Elephteria", the } \\
\text { children's choir and } \\
\text { theatre "Lastochki" } \\
\text { (Swallows). }\end{array}$ \\
\hline & & $\begin{array}{l}\text { Krasnoda } \\
\mathrm{r} \\
\text { Territory }\end{array}$ & 26.4 & 0.4 & & $\begin{array}{l}\text { Festival of the Greek } \\
\text { Culture, Krasnodar } \\
\text { Municipal public } \\
\text { organization of the } \\
\text { Greeks "Pontos", } \\
\text { Hellenic folk dance } \\
\text { group "Pontos", } \\
\text { children's Hellenic } \\
\text { dance group } \\
\text { "Eftihia". }\end{array}$ \\
\hline
\end{tabular}

Source: developed by the authors based on Greeks of Russia (2020) and German National District (2020) 
Table 2

Estimated Probability of Changes in the Language Spoken by Residents of the Bashkortostan

\begin{tabular}{|c|c|c|c|c|c|c|c|}
\hline $\begin{array}{l}\text { District } \\
\text { (“Raion") }\end{array}$ & $\begin{array}{c}\text { Populat } \\
\text { ion }\end{array}$ & $\begin{array}{c}\text { Numbe } \\
\text { r of } \\
\text { ethnic } \\
\text { Chuvas } \\
\text { hes }\end{array}$ & $\begin{array}{c}\text { Chuvas } \\
\text { h } \\
\text { languag } \\
\text { e/dialec } \\
t\end{array}$ & $\mathbf{m}$ & $\Delta \mathbf{S}$ & $\begin{array}{c}\text { Proport } \\
\text { ion of } \\
\text { the } \\
\text { Chuvas } \\
\text { hes } \\
\text { speakin } \\
\text { g } \\
\text { Chuvas } \\
\text { h } \\
\text { languag } \\
\text { e }\end{array}$ & $\begin{array}{c}\text { Likelih } \\
\text { ood of } \\
\text { changes } \\
\text { in the } \\
\text { commu } \\
\text { nity's } \\
\text { main } \\
\text { languag } \\
\text { e \% }\end{array}$ \\
\hline
\end{tabular}

\begin{tabular}{|c|c|c|c|c|c|c|c|}
\hline Alsheyevsky & 48398 & 952 & $\begin{array}{l}\text { Chuvash } \\
\text { languag } \\
\mathrm{e}\end{array}$ & 0.02 & 0.02 & - & 2 \\
\hline Belebeevsky & 17360 & 3637 & dialect & 0.21 & 0.27 & - & 27 \\
\hline Bizhbulaksky & 27999 & 10004 & dialect & 0.36 & 0.56 & - & 56 \\
\hline Yermakeevsky & 18205 & 2639 & $\begin{array}{c}\text { Chuvash } \\
\text { languag } \\
\mathrm{e}\end{array}$ & 0.15 & 0.18 & 92.2 & 18 \\
\hline Miyakinsky & 31789 & 3090 & dialect & 0.10 & 0.11 & 96.5 & 11 \\
\hline Sterlibashevsky & 22007 & 589 & $\begin{array}{c}\text { Chuvash } \\
\text { languag } \\
\mathrm{e}\end{array}$ & 0.03 & 0.03 & - & 3 \\
\hline Fedorovsky & 19675 & 2404 & dialect & 0.12 & 0.13 & - & 13 \\
\hline \multicolumn{8}{|c|}{$2^{\text {nd }}$ area } \\
\hline Arkhangelsky & 20165 & 549 & $\begin{array}{c}\text { Chuvash } \\
\text { languag } \\
\mathrm{e}\end{array}$ & 0.03 & 0.03 & - & 3 \\
\hline Aurgazinsky & 38996 & 11740 & dialect & 0.30 & 0.43 & 97.7 & 43 \\
\hline Gafuriysky & 36761 & 3013 & dialect & 0.08 & 0.09 & - & 9 \\
\hline Davlekanovsky & 18278 & 1191 & dialect & 0.07 & 0.08 & - & 8 \\
\hline Iglinsky & 45392 & 3432 & $\begin{array}{c}\text { Chuvash } \\
\text { languag } \\
\mathrm{e} \\
\end{array}$ & 0.08 & 0.09 & - & 9 \\
\hline Ishimbaysky & 25910 & 1189 & dialect & 0.05 & 0.05 & - & 5 \\
\hline
\end{tabular}




\begin{tabular}{|c|c|c|c|c|c|c|c|}
\hline Karmaskalinsky & 54585 & 5238 & dialect & 0.10 & 0.11 & 95.9 & 11 \\
\hline Sterlitamaksky & 37699 & 5190 & dialect & 0.14 & 0.16 & - & 16 \\
\hline Ufimsky & 26351 & 1357 & dialect & 0.05 & 0.05 & - & 5 \\
\hline \multicolumn{8}{|c|}{$3^{\mathrm{d}}$ area } \\
\hline Bakalinsky & 32327 & 1049 & $\begin{array}{c}\text { Chuvash } \\
\text { languag } \\
\mathrm{e}\end{array}$ & 0.03 & 0.03 & - & 3 \\
\hline Tuymazinsky & 30923 & 585 & $\begin{array}{c}\text { Chuvash } \\
\text { languag } \\
\mathrm{e}\end{array}$ & 0.02 & 0.02 & - & 2 \\
\hline Sharansky & 24494 & 2510 & $\begin{array}{c}\text { Chuvash } \\
\text { languag } \\
\mathrm{e}\end{array}$ & 0.10 & 0.11 & - & 11 \\
\hline $\begin{array}{c}\text { Chekmagushevsk } \\
\mathrm{y}\end{array}$ & 33031 & 1028 & $\begin{array}{l}\text { Chuvash } \\
\text { languag } \\
\mathrm{e}\end{array}$ & 0.03 & 0.03 & - & 3 \\
\hline \multicolumn{8}{|c|}{$4^{\text {th }}$ area } \\
\hline Zianchurinsky & 30091 & 319 & $\begin{array}{c}\text { Chuvash } \\
\text { languag } \\
\mathrm{e}\end{array}$ & 0.01 & 0.01 & 64.9 & 1 \\
\hline Zilairsky & 18939 & 563 & dialect & 0.03 & 0.03 & 70.9 & 3 \\
\hline Kugarchinsky & 34203 & 637 & $\begin{array}{c}\text { Chuvash } \\
\text { languag } \\
\mathrm{e}\end{array}$ & 0.02 & 0.02 & 70.8 & 2 \\
\hline Kuyurgazinsky & 25587 & 1882 & dialect & 0.07 & 0.08 & - & 8 \\
\hline Meleuzovsky & 26723 & 672 & $\begin{array}{c}\text { Chuvash } \\
\text { languag } \\
\mathrm{e}\end{array}$ & 0.03 & 0.03 & 70.5 & 3 \\
\hline Khaibullinsky & 33072 & 216 & $\begin{array}{c}\text { Chuvash } \\
\text { languag } \\
\mathrm{e}\end{array}$ & 0.01 & 0.01 & - & 1 \\
\hline
\end{tabular}

Source: developed by the authors based on Regional Encyclopedic Portal (2020) and Safin et al. (2018)

Without getting into specifics, the changes in the Chuvash language are worth being searched through the lens of the proportion of Chuvash residents in the population of certain areas. In Table 2, those are grouped by their peculiar speech patterns (Vlasova, 2005). The mathematical model was applied to define the probability of linguistic changes in focal regions 
of Bashkortostan and the relationship between these likely changes and the percentage of those people in each region speaking the Chuvash language.

By relating the probability of the host language replacement with the newcomers' language to the number of Chuvash people speaking the Chuvash language (Figure 3), the direct dependence is revealed between those figures. Thus, the more Chuvash people use their native language in everyday living, the higher is the probability of the residents' language replacement in the specific locality of Bashkortostan.

\section{Figure 3}

Relationship between the Probability of the Host Language Replacement and the Number of Chuvash People Speaking the Chuvash Language

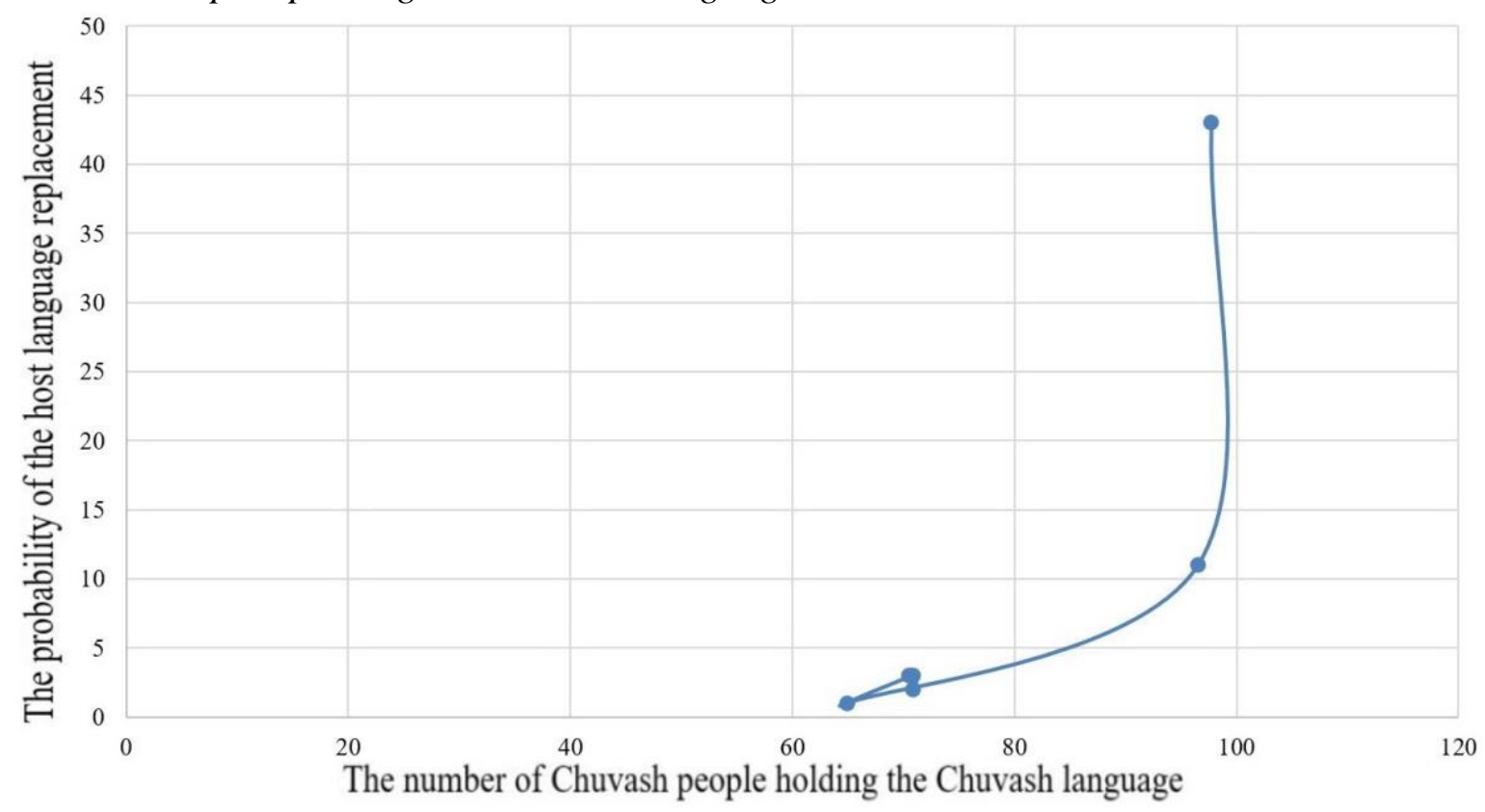

Source: developed by the authors

The probability of Chuvash language replacing the host language within the range of 5$10 \%$ is defined for six districts, including Gafuriysky, Davlekanovsky, Iglinsky, Ishimbaysky, Ufimsky, and Kuyurgazinsky districts; all of them (apart from Iglinsky district) have peculiar dialects. The probability of the language replacement varying from 11 to $50 \%$ was estimated for eight districts: Belebeevsky, Yermakeevsky, Miyakinsky, Fedorovsky, Aurgazinsky, Karmaskalinsky, Sterlitamaksky, and Sharansky; specific dialects are their common feature (except for Yermakeevsky and Sharansky districts). Bizhbuliaksky district shows the recordbreaking probability of the host language substitution by Chuvash language at $56 \%$.

The present study has revealed that the people living in Bashkortostan are steadfast in their cultural traditions. Although they have changed their place of residence long ago, the Chuvash people keep following their age-long traditions and speaking their native language. On the other hand, Chuvash was also influenced by Tatar, Bashkir, Russian, and other surrounding languages.

\section{Discussion}

Agreeing that under cultural fusion people employ their intrinsic ability to adjust to the environment (Croucher \& Kramer, 2017), the case of the Chuvash people suggests, that an individual tends to preserve his/her cultural identity even being in the minority amidst the members of a different culture (Safin et al., 2018). To put it in other words, through centuries 
of living among the dominating (97\%) nation speaking a different language, three-quarters of this ethnic minority group were able to preserve their language (Sadikov, 2016).

The new environment has a specific impact on both culture in general and language in particular. It is a proven fact that on the borderlines where several languages intersect, some changes appear in the language of even the most conservative members of society (Hassan \& Bezbaruah, 2020). The Chuvash language is not an exception. Thus, there are four areas and 13 dialects within the Republic of Bashkortostan (Vlasova, 2005), shaped up under the influence of Bashkir, Russian, Tatar, Mari, Udmurt, and other surrounding languages. All of them are characterized by variations that all Chuvashes use in their speech, but each one also has features that are known only in the specific area (Akhvanderova \& Korotaeva, 2018). The low population density, which makes in the region 28.5 people per 1 sq. $\mathrm{km}$ (Safiullin et al., 2017), prevents the expansion of peculiar linguistic phenomena in surrounding areas.

The long stay of migrants in the host country does not dilute the use of the national migrants' language. A particularly representative case is the Chinese migration to the United States, a number of migrant groups in Canada, as well as traditional Greek families living in other countries for a long time (Paquet $\&$ Xhardez, 2020). Their behavior and the predominant preservation of the national language fully correspond to the results obtained in this study regarding Chuvashes' behavior in a Russian region (Paquet \& Xhardez, 2020; Paulsen, 2020). The cultural structure of ethnic Greeks is similar according to the indicated studies. The use of predominantly one national language in most spheres of life and coexistence with numerous ethnic groups is typical for the USA, Canada, Germany, and other modern developed countries (Dounia, 2020). For an accurate statistical comparison, these countries should be studied using the same methodology as for the Russian Federation. For this, similar statistical data are sufficient, and such a study should be classified as a follow-up. The latest available empirical research data demonstrate a high similarity of trends in the behavior of ethnic groups in similar conditions.

Several scenarios are presumed for Bashkortostan Republic from the multiculturalist prospects; one of them consists in the gradual blending of cultures as part of the ongoing contacts between members of the different cultures, for instance, through inter-ethnic marriage and acceptance of the host country culture. The second scenario suggests the foreign culture to be predominant if the ethnic community's size and time of residence in the Republic are sufficient for its impact to be on full display. Under the third scenario, changes will occur in the minority culture either as a result of new forms brought by the migrant students or retired people coming back home from abroad (Khilazheva, 2019). Though, given current migration trends, the second scenario is highly doubtful due to the temporary and sporadic nature of such migration. The first and the third scenarios look more probable. However, their implications for the centuries-old culture of the Chuvash people may be rather ruinous, given that they constitute only 3\% of the Republic's population. Moreover, the acculturation and assimilation of these people proved to be set in motion in some regions of the Republic (Afanasiev \& Shash, 2019; Safin et al., 2018).

\section{Conclusions}

The Russian Federation is a home for over 160 ethnic cultures belonging to either migrants or descendants of those who once migrated to Russia for some reason. Typically, the host country culture dominates the cultural fusion; however, the minority group can also influence the predominant culture. For instance, back in the day, the Hellenic migrant community brought Christianity to Russia, while the Lutheran Church came here with the Germans. Migrants from Germany and Greece enriched the Russian cuisine, brought the German pedantry, punctuality, ethnic dance art, etc. to the host population. Meanwhile, their 
cultural background (including their native language) has been nearly lost, and currently, the ethnic community work to revive it through supplementary schools and language centers.

In the case of Chuvash migrants in Bashkortostan, changes were found in a cultural setting, specifically in migrants' language and cultural fusion in the community. The study demonstrated a high usage of the ethnic language among migrants, despite the dominance of the Russian language. Over $75 \%$ of the Chuvash people speak Chuvash language, though most of them can also speak surrounding languages, like Tatar, Bashkir, Russian, and others. It was found that the Chuvash language underwent some changes and acquired specific features in different regions of the Republic, which allowed the linguistic researchers to identify four areas and 13 dialects, while in some Bashkortostan regions, the Chuvash migrant descendants entirely assimilated and forgot their native language. According to mathematical modeling results, the preservation of the native migrants' language in everyday living demonstrates a high probability of host language replacement by the migrant language in their environment (the probability is $5-10 \%$ higher than the expected level for 7 districts and 11 to $50 \%$ - in 8 districts out of 26 studied).

An important study implication lies in the Bashkortostan's cultural context under the influence of the foreign culture, which has been evaluated within the scope of current patterns and trends in migration. Similar processes can occur in many multi-ethnic countries and in connection with the active international migration, for example, in the USA and Germany as attractors of migration flows. The research findings show that given the low profile of both cross-border and internal migration flows at this moment, the current trend towards the Chuvash traditional culture shrinking will hold slowly though steadily.

The research suggests expanding the multiculturalism policy and supporting the use of individual ethnic groups' languages in multi-ethnic societies.

\section{References}

Afanasiev, M. P., \& Shash, N. N. (2019). Russian federation cross-border investments and bank expansion in Russia. Public Administration Issue, 6, 105-120. https://doi.org/10.17323/1999-5431-2019-0-6-105-120

Akhvanderova, A. D., \& Korotaeva, L. V. (2018). Dialect vocabulary denoting actions and states of subjects in the Chuvash dialects of the Republic of Bashkortostan. Bulletin of ChGPU, 3(99), 26-31.

Bhugra, D., Watson, C., \& Ventriglio, A. (2020). Migration, cultural capital and acculturation. International Review of Psychiatry, 33(1-2), 126-131. https://doi.org/10.1080/09540261.2020.1733786

Croucher, S. M., \& Kramer, E. (2017). Cultural fusion theory: An alternative to acculturation. Journal of International \& Intercultural Communication, 10(2), 97-114. https://doi.org/10.1080/17513057.2016.1229498

Dounia, M. (2020). Transnational practices and emotional belonging among early 20th-century Greek migrants in the United States. Genealogy, 4(3), 90. https://doi.org/10.3390/genealogy4030090

Erten, E. Y., van den Berg, P., \& Weissing, F. J. (2018). Acculturation orientations affect the evolution of a multicultural society. Nature Communications, 9(1), 58. https://doi.org/10.1038/s41467-017-02513-0

Fox, M., Thayer, Z., \& Wadhwa, P. D. (2017). Assessment of acculturation in minority health

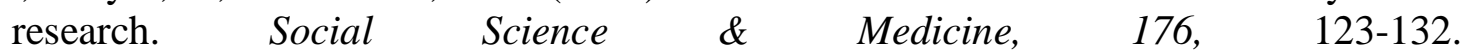
https://doi.org/10.1016/j.socscimed.2017.01.029

German National District. (2020). Official site of German National District in the Altai Territory. Retrieved March 3, 2021, from http://www.admin-nnr.ru/ 
Greeks of Russia. (2020). Federal national and cultural autonomy of Greeks of Russia. Retrieved March 3, 2021, from https://rusgreek.ru/

Gurer, C. (2019). Refugee Perspectives on Integration in Germany. American Journal of Qualitative Research, 3(2), 52-70. https://doi.org/10.29333/ajqr/6433

Gurieva, S., Kõiv, K., \& Tararukhina, O. (2020). Migration and adaptation as indicators of social mobility migrants. Behavioral Sciences, $10(1), \quad 30$. https://doi.org/10.3390/bs10010030

Haenni Hoti, A., Wolfgramm, C., Müller, M., Heinzmann, S., \& Buholzer, A. (2019). Immigrant students and their teachers-exploring various constellations of acculturation orientations and their impact on school adjustment. Intercultural Education, 30(5), 478494. https://doi.org/10.1080/14675986.2019.1586214

Hassan, M., \& Bezbaruah, M. P. (2020). Inequality in the dynamics of development: Postglobalisation changes and 21st century challenges. Space \& Culture, India, 8(1), 68-77. https://doi.org/10.20896/saci.v8i1.701

International Organization for Migration. (2020). World Migration Report. Retrieved March 3, 2021, from https://publications.iom.int/system/files/pdf/wmr_2020.pdf

Jamal, A., Kizgin, H., Rana, N. P., Laroche, M., \& Dwivedi, Y. K. (2019). Impact of acculturation, online participation and involvement on voting intentions. Government Information Quarterly, 36(3), 510-519. https://doi.org/10.1016/j.giq.2019.04.001

Khilazheva, G. F. (2019). The contribution of international migration to the demographic and migration potential of the Republic of Bashkortostan. In Human potential of Russia of the 20th century in the context of modernization (pp. 186-191). Yekaterinburg: Institute of Economics of the Ural Branch of the Russian Academy of Sciences.

Melkonian, M., Areepattamannil, S., Menano, L., \& Fildago, P. (2019). Examining acculturation orientations and perceived cultural distance among immigrant adolescents in Portugal: Links to performance in reading, mathematics, and science. Social Psychology of Education, 22(4), 969-989. https://doi.org/10.1007/s11218-020-09542-6

Nasritdinov, E. (2016). 'Only by learning how to live together differently can we live together at all': Readability and legibility of Central Asian migrants' presence in urban Russia. Central Asian Survey, 35(2), 257-275. https://doi.org/10.1080/02634937.2016.1153837

Nayar, S., \& Wright St.Clair, V. (2020). Multiple Cultures - One Process: Undertaking A Cross Cultural Grounded Theory Study. American Journal of Qualitative Research, 4(3), 131145. https://doi.org/10.29333/ajqr/9310

Nikiforova, E., \& Brednikova, O. (2018). On labor migration to Russia: Central Asian migrants and migrant families in the matrix of Russia's bordering policies. Political Geography, 66, 142-150. https://doi.org/10.1016/j.polgeo.2018.04.006

Paquet, M., \& Xhardez, C. (2020). Immigrant integration policies when regions decide 'who comes in': The case of Canadian provinces. Regional Studies, 54(11), 1519-1534. https://doi.org/10.1080/00343404.2020.1808881

Paulsen, D. (2020). Preserving native culture on a foreign ground-traditional Chinese culture among Chinese immigrant New Yorkers [Master's thesis]. University of Oslo.

Rasool, S., \& Zhang, J. (2020). Bangladeshi, Indian, and Pakistani Parents' Perceptions of Their Children's Academic Achievement in Southwest Florida. American Journal of Qualitative Research, 4(3), 146-160. https://doi.org/10.29333/ajqr/9337

Regional Encyclopedic Portal. (2020). Bashkir encyclopedia. Retrieved March 3, 2021, from http://www.bashenc.ru/

Ruchkin, V. A., Eremin, S. G., Zaitseva, E. A., Zamylin, E. I., \& Pechnikov, G. A. (2019). Migration processes and socio-economic development of the regions. Amazonia Investiga, 8(24), 516-525. 
Russian Federal State Statistics Service. (2020). Rossta. Retrieved March 3, 2021, from https://www.gks.ru/

Ryabichenko, T. A., \& Lebedeva, N. M. (2016). Assimilation or integration: Similarities and differences between acculturation attitudes of migrants from Central Asia and Russians in Central Russia. Psychology in Russia: State of the art, 9(1), 98-111. https://doi.org/10.11621/pir.2016.0107

Ryazantsev, S., Bogdanov, I., Dobrokhleb, V., \& Lukyanets, A. (2017). Migration from central Asian countries to Russia and Kazakhstan in the context of integration processes in the Eurasian Economic Union Format. Central Asia \& the Caucasus, 18(1), 39-49.

Sadikov, R. R. (2016). 'Pagan' religions in the Republic of Bashkortostan. Proceedings of Kuzeev Institute for Ethnological Studies, 2, 101-106.

Safin, F. G., Mukhtasarova, E. A., \& Khaliulina, A. I. (2018). Ethnodemographic and ethnolinguistic problems of the Chuvash population of Bashkortostan. Bulletin of the Chuvash University, 4, 163.

Safiullin, R. G., Afanasyev, A. K., Safiullina, R. M., \& Safiullin, M. R. (2017). The impact of migration on human capital development in the Republic of Bashkortostan. In Demographic potential of the EEU countries: 8th Ural Demographic Forum (vol. 2, pp. 352-359). Yekaterinburg: Institute of Economics, Ural Branch of Russian Academy of Science.

Sardadvar, S., \& Vakulenko, E. (2017). A model of interregional migration under the presence of natural resources: Theory and evidence from Russia. The Annals of Regional Science, 59(2), 535-569. https://doi.org/10.1007/s00168-017-0844-3

Sardadvar, S., \& Vakulenko, E. (2020). Estimating and interpreting internal migration flows in Russia by accounting for network effects. Socio-Economic Planning Sciences, 69, 100685. https://doi.org/10.1016/j.seps.2019.01.007

Schachner, M. K., He, J., Heizmann, B., \& Van de Vijver, F. J. (2017). Acculturation and school adjustment of immigrant youth in six European countries: Findings from the Programme for International Student Assessment (PISA). Frontiers in psychology, 8, 649. https://doi.org/10.3389/fpsyg.2017.00649

Syzdykova, Z., Medvedev, N., Suleymanova, S., Nazarova, E., \& Volokh, V. (2020). Governance of cross-border migration in Asia. Space \& Culture, India, 7(4), 264-273. https://doi.org/10.20896/saci.v7i4.568

United Nations Department of Economic and Social Affairs. (2020). Population division. Retrieved March 3, 2021, from https://www.un.org/development/desa/pd/

Urzúa, A., Ferrer, R., Gaete, V. C., Aragón, D. N., Labraña, I. R., \& Poblete, B. T. (2017). The influence of acculturation strategies in quality of life by immigrants in Northern Chile. Quality of Life Research, 26(3), 717-726. https://doi.org/10.1007/s11136-016-1470-8

Vlasova, L. V. (2005). The phonetic and lexical systems in the sub-dialects of the Chuvash people from the Trans-Ural region of Bashkortostan. Comparative historical research. Synopsis of a thesis for academic degree of the Cand. Sc. Philology.

Zhanbossinova, A. S., Karibaev, M., Atantayeva, B., Kulshanova, A., \& Shaimerdenova, M. (2019). Socio-cultural adaptation of repatriates of East Kazakhstan and migration attitudes of the Kazakhs of Mongolia. Space \& Culture, India, 7(1), 154-169. https://doi.org/10.20896/saci.v7i1.414 


\section{Notes on Contributors}

Olga Kobzeva is a Doctor of Historical Sciences, Professor of the Department of Uzbekistan's History, National University of Uzbekistan named after Mirzo Ulugbek, Tashkent, Uzbekistan. Her research interests include homeland traditions, migrant community, cultural influence, cultural changes, ethnic groups, native cultures, native languages, Cultural Effects of Migration, Migration, and Migrants.

Elena Kolomoets is a $\mathrm{PhD}$ of Philosophical Sciences, Associate Professor of the Department of Sociology, Psychology and Social Management, Moscow Aviation Institute (National Research University), Moscow, Russia, e-mail. Her research interests include homeland traditions, cultural influence, cultural changes, native cultures, Cultural Effects of Migration, Migration, and Migrants.

Artem Lukyanets is a $\mathrm{PhD}$ of Economic Sciences, Associate Professor of the Department of Demographic and Migration Policy, Moscow State Institute of International Relations (MGIMO), Institute of Socio-Political Research FCTAS RAS, Moscow, Russia. His research interests include migrant community, differential equation, mathematical modeling, Migration, and Migrants.

Larisa Korotaeva is a $\mathrm{PhD}$ of Philological Sciences, Associate Professor of the Department of Tatar and Chuvash Philology, Sterlitamak Branch of the Federal State Budgetary Educational Establishment of the Higher Education "Bashkir State University", Sterlitamak, Republic of Bashkortostan, Russia. His research interests include host language, local language, cultural changes, ethnic groups, native languages, Language Effects of Migration, Migration, and Migrants. 